\title{
Hittite causative markers in a diachronic Anatolian perspective ${ }^{1}$
}

\begin{abstract}
Hittite is a heavily transivitizing language, and there are several morphological markers of causativisation in Hittite. Two of them, namely suffixes - $n u$ - and -ahh-, were productive in the history of Hittite. Other markers are either no longer productive or primarily not causative. In Old Hittite - $n u$ - and -ahh- still had some kind of complementary distribution, although there already was some overlapping, but in Middle and especially New Hittite these markers became nearly interchangeable. The coexistence of $-n u$ - and -ahh-derivatives from the same bases can be attributed, at least partially, to an imperfect knowledge of Hittite by Luwian scribes.
\end{abstract}

Keywords: Hittite language; causative markers; verbal morphology; iterative forms; intensive forms; Luwian language.

\section{Introduction. Causative markers in Hittite}

Hittite is a heavily transitivizing language (see a detailed discussion in Luraghi 2012), which features a large number of causative verbs. Nevertheless, the number of causative markers found in Hittite, both productive and fossilized, is surprising. In total, five markers, namely the suffixes $-n u-,-a h h$ - and $-e^{-2}$ as well as reduplication and the nasal infix, can have causative semantics. These causative markers differ in frequency and diachronic distribution, but all of them were inherited from Proto-Indo-European and have counterparts in other IndoEuropean languages. The two most common causative markers in Hittite are the suffixes $-n u-$ and -ahh-, which could be added to verbs as well as adjectives and nouns. ${ }^{3}$ Overall, there are about $130 n u$-verbs and $75 a h h$-verbs; this makes them two of the most prominent verbal classes in Hittite. In de-adjectival derivation, these suffixes were often used next to fientives in $-\bar{e}$ - and its enlarged variant -ess- (see Oettinger 1979: 238ff.), and could be added virtually to any descriptive adjective in Hittite. The other three causative markers are attested only in a few verbs each and are either no longer productive in Hittite (the suffix - $e$ - and the infix) or primarily not causative (reduplication). In the following section I shall first discuss each of the causative markers, including their origin, and then address their distribution.

\section{Causative suffixes in Hittite}

\subsection{The suffix -nu-}

The suffix -nu-, the most frequent causative marker, can be found added to both verbs and adjectives already in the earliest texts. There are two denominal $n u$-verbs as well: ēsharnu-

\footnotetext{
${ }^{1}$ This research has been supported by the Russian foundation for basic research (project № 19-012-00581 "Valency alternations in Hittite, Old Armenian and Ossetic in diachronic and comparative perspective"). I am thankful to D. Sasseville, who made his dissertation available to me ahead of publication.

${ }^{2}$ This suffix is found in lukke- 'to kindle, set on fire' and wasse- 'to dress (someone)', see Eichner 1969: 31f. and Watkins 1973: 68f.

${ }^{3}$ The suffix -ahh-could also be added to the numerals, see Kronasser 1966: 430.
} 
'to make bloody, red', derived from ēshar 'blood', ${ }^{4}$ and KAL-tarnu- ( ${ }^{*}$ hatugatarnu-) 'to make formidable', derived from hatugātar 'terribleness, terror'. This suffix is well attested in many other Indo-European languages and was clearly present already in PIE (cf. LIV: 17f.). Yet there is only one Hittite $n u$-verb that has lexical cognates in non-Anatolian IE languages: Hitt. arnu'to make go, stir, remove, deliver' vs. Gr. ọ̋vvuı 'to stir up, make to arise, incite', Skt. rnóti 'to move, put in motion'. Another $n u$-verb that was allegedly inherited from PIE is tepnu'to diminish'. It has been compared to Skt. dabhnóti 'deceives' (see e.g. LIV: 132), while Koch (1980: 235f.) suggested that the suffix -nu-, seen in tepnu- 'to diminish' and Skt. dabhnóti 'to damage', is in fact a reanalysis of the infix * $n$ - inserted into the adjectival stem *dhebhu- 'little'. This is, however, hardly possible, since tepnu- is mostly found in New Hittite texts as well as a few Middle Hittite texts, see Hoffner 1977: 152ff. Given that the suffix -nu- was extremely productive and that the meaning of Hitt. tepnu- 'to diminish' is based on têpu- 'small' and is quite different from that of the Sanskrit verb ('to deceive, heart'), tepnu- is likely to represent a Hittite de-adjectival formation, which could also explain the full grade of the root, see Shatskov 2017: 197f. Besides, there seems to be no special connection between $u$-stem adjectives and verbal $n u$-stems in other IE languages. For instance, in Sanskrit $u$-adjectives often occur beside causatives in -áya- or infixed stems, e.g. Skt. svädú- 'sweet' and Skt. svadáyati 'to season sweeten' or Skt. prthú- 'broad wide' and Skt. pratháyati 'to make spread out', cf. further Rau 2009: 170ff. and 183f. In late PIE the suffix*-neu/nu- and the infix *-ne/n- were clearly different morphemes, even though they may ultimately be cognate. ${ }^{5}$

The suffix $-n \mathcal{u}$ - is also attested in Luwian as well as in Lycian and Lydian, see Sasseville 2018: 91ff. However, despite the fact that this stem was common both in Hittite and Luwian, the cognates are few: CLuw. asharnu- 'to make red, bloody' vs. Hitt. ésharnu- 'id.', CLuw. and HLuw. huinu- 'to make run' vs. Hitt. huinu- 'id.', CLuw. and HLuw. marnuwa- 'to make disappear' vs. Hitt. mernu- 'id.', perhaps also HLuw. asunu- 'to make good?' vs. Hitt. as(sa)nu- 'to take care of'. HLuw. zahhanuwa- 'to attack' seems to have a parallel in Hitt. zahhiyanu- 'to attack', but the latter is attested only once and apparently based on Hitt. zahhiya- 'to attack', so it must be an inner-Hittite formation, if this form is real at all. ${ }^{6}$ The low number of correspondences indicates that most Hittite and Luwian $n u$-verbs were formed after the breakup of Proto-Anatolian.

\subsection{The suffix -ahh-}

In Old Hittite -ahh- was used to derive causatives (factitives) from adjectives and nouns, but later this suffix started to be added to verbs as well, cf. e.g. tarup(iy)ahh-from tarupp- 'to unite, collect' or kartimmiyahh- 'to make angry' from kartimmiye/a- 'to be angry', see Shatskov 2017: 226f.

Hittite causatives in -ahh- have cognates in Luwian, Lycian and Lydian stems in - $a$ - (Melchert 1997: 332, Sasseville 2018: 15ff.). This class is well attested in both Luwian and Lycian, but correspondences with Hittite are few, the only secure example being Hitt. marsahh- 'to desecrate' (next to the better attested marsanu-) and Luw. marsa- 'to commit a treachery (?)', Lyc. mrssxa- 'to desecrate' (Sasseville 2018: 25f., 41). Another possible example is Hitt. dannattahh- 'to devastate' and Luw. tannatta- 'to devastate', though the Hittite adjective dannatta-

\footnotetext{
${ }^{4}$ Since èsharnu- is cognate to Luw. asharnu- 'to make bloody', denominal nu-verbs must be of Proto-Anatolian age.

${ }^{5}$ For various theories concerning the origin of the infix in PIE and its relation to the suffix ${ }^{*}$-neu-cf. e.g. Milizia 2004 and Steer 2013-14.

${ }^{6}$ The verbs zahhiya- and zahhiyanu- are used in the same text and in the same context, cf. KBo 3.4 II $25 n=a n$ DUTUŠs zahhiyanun and II $60 n=a n$ DUTU šl MÈ-yanunun 'and I, My Majesty, attacked him', and the extra -nu- sign in MÈ-ya-nu-nu-un may well be a scribal error.
} 
may be a Luwian borrowing, and in that case its derivative dannatahh- is a late and independent formation (Sasseville 2018: 35).

The suffix -ahh- has cognates in other IE languages (cf. e.g. Latin novāre 'to make new, renew', Gk. veó $\omega$ 'to plough up a fallow land' and Hitt. newahh- 'to renew') and was evidently employed in formation of deadjectival verbs, cf. e.g. Fortson 2010: 99f. Sasseville (2014-15, 2018: 56ff.) argued that causative verbs in ${ }^{*}-e h_{2^{-}}$are derived from nouns in ${ }^{*}-e h_{2^{-}}$via conver-

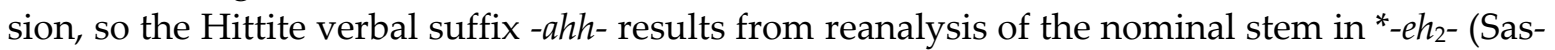
seville 2018: 60f.). However, in that case the predominantly de-adjectival derivation of such stems in Hittite and Latin ${ }^{7}$ must be an independent innovation, whereas the denominal derivation was preserved as its basic function only in Lycian. If the verbal suffix is indeed cognate with nominal stems in ${ }^{*} h_{2}$, one could perhaps assume that the reanalysis of the nominal stem as the verbal factitive stem occurred already in PIE.

\subsection{The suffix $-e-$}

A common PIE causative marker was the suffix *-éye/o-, accompanied by the vocalism ${ }^{*} O$ in the root (e.g. Fortson 2010: 99, LIV: 22f.). ${ }^{8}$ The Hittite reflex of this suffix, $-e-$, is preserved only in two verbs: wasse- 'to put on' next to wass- 'to be dressed' and lukke- 'to set fire to' next to lukk'to become light'. The causative stem in -e- clearly was no longer morphologically transparent, and eventually it was replaced with other stems: cf. luk- in lukkun (KBo 12.38 III 9, NH) or wassiya- in wassiyanzi (e.g. KUB 9.31 II 11, MH/NS). PIE causative *éyelo- stems are likely to be continued by several Hittite hi-conjugation verbs including lak- to 'fell' and kank- 'to hang'; in the prehistory of Hittite these formations presumably lost the suffix *éye/o- and shifted to the hi-conjugation, see Schulze-Thulin 2001 and Kloekhorst 2008: 437f, 514f. Kloekhorst (2008: 532, 1006f.) also argues that wasse- and lukke- have the suffix *-ye/o- rather than causative-iterative *-éye/o-. Note, however, that both lukke- and wasse- have *éye/o-counterparts in other IndoEuropean languages: Skt. rocáyati, Latin lucēo 'to cause to shine', Skt. vāsáyati, Goth. wasjan 'to dress' (LIV: 419, 692). Besides, Kloekhorst's examples of mi-conjugation *-ye/o- stems next to unextended middle stems (huett-tta(ri) and huttiye-zi 'to pull', hatt-a(ri) and hazzie-zi 'to pierce') show no semantic distinction between middle and ye/o-stems, whereas lukke- and wasseclearly differ from the respective middle stems and do have a causative meaning.

The reflexes of PIE causatives-iteratives in *éye/o- are better preserved in other Anatolian languages, see Sasseville 2018: 184ff., 208ff., 211f., though there are no exact lexical matches with Hittite.

\subsection{The infix}

Infixed verbs are well attested in Hittite, although they are not very numerous, cf. hark- 'to perish' vs. harnink- 'to destroy' or istark- 'to ail, become ill' vs. istarnink- 'to make ill'. Two other Hittite verbs with the infix -ni(n)- do not have the infixless counterparts preserved: sarnink- 'to compensate' (cf. Lat. sarciō 'to repair') ${ }^{9}$ and ninink- 'to set in motion, disturb' (cf. Lith. ap-ninkù, -nikti 'to assault, beset', $i$-nikti 'to get down to, engage, attack', ap-nikti 'to energetically get down to; beset', Gr. veĩkoৎ 'quarrel'). Finally, hunink- 'to scar, crack' 10 is not causative as it is

${ }^{7}$ On this type in Latin, cf. e.g. Leumann 1977: 546.

${ }^{8}$ Stems in *éye/o- may also have the iterative-intensive value. On the polysemy of this suffix see 3.1 below.

${ }^{9}$ Kloekhorst (2008: 734f.) argues that the underlying stem sark- is attested in sarkiske- which he translates as 'to be good, eminent' rather than 'to ascend', as e.g. in CHD Š: 267.

${ }^{10}$ On the meaning of hunink-, see Shatskov 2017: 27ff. 
based on huek- 'to slaughter'. ${ }^{11}$ As argued in Shatskov 2017: 62, the infix -nin- was a productive way of deriving causatives in proto-Hittite; however, in late Hittite the infixed stem was apparently no longer transparent and could be replaced with a -nu-stem, as in the case of harnink- 'to destroy', which was substituted in some texts with harganu- 'id.' (Ünal 1984: 77f.).

While there are no infixed verbs in Luwian, the infix is preserved in both Palaic and Luwian as a part of the suffix -ina- (Sasseville 2018: 455f).

\subsection{Reduplication}

A secure example of the Hittite causative reduplicated formation is asās-/ases- 'to install, settle' derived from $\bar{e} s$ - 'to sit'. Two more likely examples are titta- 'to install' 12 and lilakk- 'to fell, cut down'. Dempsey (2015: 99) considers lilakk- to have imperfective semantics since the verbs that stand next to lilakk- in the only preserved context have the imperfective suffixes -ske/a- and -anna/i-. ${ }^{13}$ However, the active forms of the parent verb lak-are not attested with the meaning 'to fell' and mean rather 'to knock out (a tooth)' or 'to turn (ear or eyes)', see CHD L-N: 17f. In my opinion, lilakk- is a causative to middle intransitive forms of lak- that mean 'to fall' and in that respect is similar to laknu- 'to fell' derived from the same verb or karsanu- 'to stop (tr.)', which must have been derived from the middle intransitive stem kars- 'to stop (intr.), withhold' rather than from its active counterpart that means 'to cut' (see Shatskov 2017: 148). Nevertheless, the majority of reduplicated verbs clearly have the iterative or intensive semantics, see Dempsey 2015: 331f.

The reduplicated verbs in Luwian likewise generally have iterative, durative or similar meanings (Dempsey 2015: 255). Reduplication is also well attested in other PIE branches, and one of its functions is causativization, see Kölligan 2004: 195ff., $223 \mathrm{ff}$.

\subsection{Summary}

All in all, while all the Hittite causative markers are of PIE origin, there are only a few lexical matches between causative stems in Hittite and other Anatolian and, more broadly, IndoEuropean languages; besides there is also at least one mismatch: Hitt. parkunu- 'to cleanse' and Luw. paparkuwa- 'to cleanse' (Sasseville 2018: 27). Therefore, the majority of Hittite causatives must have been formed after the breakup of Proto-Anatolian.

\section{Polysemy of the causative markers}

The majority of Hittite causative markers show a causative-iterative polysemy. ${ }^{14}$ Crosslinguistically, causative and iterative-intensive meanings are very often expressed by the same

${ }^{11}$ Therefore, the infix may have non-causative semantics, similarly to other historical causative markers in Hittite, cf. Section 3.1 below.

${ }^{12}$ If one follows the suggestion of Melchert 2018 and Dempsey 2015: 132ff., who set apart titta/i- 'to cause to stand, install' derived from tiya- 'to step, stand' and titta/i- 'to place' derived from dai/tiya- 'to put'.

${ }^{13}$ KUB 24.8 I 2-6: [h]an[dand] us LÚMEš-us [k]uis [(sar)l]iskezzi hūwappas[=a=k]an LÚMEš-us [(GIŠ-ru m)]ān lilakki

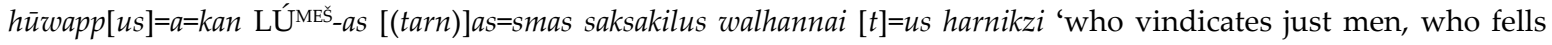
evil men like trees, who strikes evil men on their skulls like s. and destroys them.' The forms sarliskezzi and walhannai are indeed imperfective, whereas harnikzi is not.

${ }^{14}$ The suffix $-e$ - is causative in both of its preserved instances. Note, however, that in other Indo-European languages the reflexes of PIE *-éye/o- also show the same polysemy (Kölligan 2004, 2007, Kulikov 2013). 
morphemes, see e.g. Nedyalkov, Silnitsky 1973: 19f., Kittilä 2009 and Aikhenwald 2011. As I shall argue elsewhere (Shatskov forthc.), the Hittite morphemes - nu- and -ahh- show the same distribution of causative and iterative meanings as the reflexes of PIE suffix *éye/o- in Vedic and Latin. To be more precise, if derived from verbs of low semantic transitivity, - nu- and -ahh- have causative meanings, and if derived from verbs of high semantic transitivity, they have iterative or intensive meanings. The difference between - $n u$ - and -ahh-, on the one hand, and reduplication, on the other hand, is that the former are mainly causative suffixes, whereas the latter is mostly iterative-intensive in Hittite.

\section{Distribution of the causative markers}

4.1. The suffix -e-, the reflex of the very common PIE causative marker *-éye/o-, is sparsely attested in Hittite. The infix, clearly causative in Hittite and likely so in Proto-Indo-European, enjoyed limited productivity in the prehistory of Hittite but was no longer productive in the historical period (Shatskov 2017: 62f.). Reduplication is productive, but mostly used to forms imperfectives.

The only productive causative markers during the recorded period of Hittite were the suffixes - ahh- and - nu-. In the oldest texts there are causatives in - $n u$ - derived from verbs and adjectives in - $u$ - (dassanu- 'to make strong' from dassu- 'strong') and - $i$ - (parkunu- 'to cleanse' from parkui- 'clean', sallanu- 'to bring up' from salli- 'big'), while causatives in -ahh- were derived from adjectives in -ant- (dasuwahh- 'to blind' from dasuwant- 'blind') and - $i$ - (suppiyahh- 'to purify' from suppi- 'sacred, pure'). ${ }^{15}$ Thus, already in the oldest texts there was a certain overlap in the distribution of - $n u$ - and -ahh-. In later periods -ahh- started to be added to adjectives in $-u$ - as well as verbs, whereas $-n u$ - started to be added to adjectives in $-a$ - and -ant-.

4.2. There are several roots that have causatives in both -nu- and -ahh- with little, if any, difference in meaning. Note that in most cases one (or both) stems are attested only once or twice, often in damaged contexts. Cf. the following examples:

kardimiyanu- and kardimiyahh- 'to make angry'

$m \bar{a} n=m a=s ̌ t a ~ Z I^{T U M}$ DINGIRL[IM-ma ku)i]šs TUKU.TUKU-yanuzi 'If [som]eone angers the soul of go[d]' KUB 13.4 I 34 (MH/NS)

kardimiyahhanzi=an=kan kuyēs 'those who anger him' KUB 35.146 II 13 (MS)

dankuwanu- and dankuwahh- 'to make black'

[LUG]AL-us=wa kuit ēsharwah[heskitta hahlahheskitta] [da]nkuwahheskitta [harganusk]i[tta nu ap]āt EGIR-pa ANA KUR LÚKÚ[R 'and what the king [has made red, green,] dark [and white], it back to the enemy land ...' KBo 15.1 I 27-9 (NS). ${ }^{16}$

[(nu=war=a)n] tankunu[sker $k u \bar{e}\left(s=w a r=a n \quad \mathrm{SA}_{5}\right.$-nusker $\left.)\right] \quad k u \bar{e} s=w a[r=a n \quad$ ZA.GìN-nusker $]$ kunun=an [(EGIR-pa dankunuske)r] 'they make it black. They then made black those they had made red and those they had made blue.' KUB 9.34 I 4-7 (NH)

taruppiyanu- and tarupp(iy)ahh- 'to gather, collect'

${ }^{15}$ As for Hittite adjectives in - $a-$, the causatives in *-eh- (Hitt. -ahh-) could be derived from the predecessor of this type, the ${ }^{*} 0$-stem adjectives, already in PIE (see 2.2 above).

${ }^{16}$ Kümmel (1967: 113) translates this as "Womit der [Kön]ig blutrot [ge]mach[t, grün gemacht,] schwarz gemacht [(und) Weiss gemacht ist], [d]as [soll] züruck ins Feindland ...”.Yet the passive interpretation of the middle form [da]nkuwahheskitta is not obligatory, and kuit, coordinated with [ap] āt in the next clause, is likely to be a direct object here. Then [da]nkuwahheskitta is transitive despite its middle voice (unless it shall be interpreted as dankuwahheskitt=a, an active form with a connective particle $-a /-y a)$. 
LÚDAM.GÀR=ma=za=kan kuin êpta nu KÙ.BABBAR nawi daruppiyanuzi '(but (as for) the merchant who took it for himself, he has not yet collected the silver' IBoT 2.129 I 21-22 (NH)

$\left[(\mathrm{G}) \mathrm{U}_{4}\right.$-un UDU-an LÚ.U $\mathrm{U}_{19}[. \mathrm{L}] \mathrm{U}$ taruppiyahhas [ ...EGIR-p]a taruppiahhis 'gathered cattle, sheep, people ... gathered...' KUB 9.11 I 16-17 (OH/NS)

tepnu- and tepawahh- 'to diminish, demean' 17

arahzenas $=w a=m u=z a$ KUR.KUR LÚKÚR kuiēs DUMU-lan halzesser $n u=w a=m u=z a$ tepnusker 'The surrounding enemy lands who called me 'a child', they humiliated me' KBo 3.4 I 23-24 (NH) $n u=s s i=z a$ EGIR-an ŪL memas $n=a n$ ANA PANI KUR.KUR'MEš tepaw[a]hta! '(The crown prince held him by the hand), but he said "no" to him and demeaned him in the presence of the lands.' KUB 14.3 I 12-13 (NH)

wastanu- and wastahh- 'to sin'

GIM-an=ma ANA ${ }^{\mathrm{m}}$ Arnuwand[a NUMUN ēsta] man wastanunun man Š $[A$ EN=YA] NUMUN arha tarnahun 'If there had been progeny for Arnuwanda, I would have sinned, I would have let away progeny of my brother (from kingship).' KBo 12.41+ II 10-12 (NH)

]ki kuit wasta[hh] $u[n]$ 'what I sinned' 18 KUB 36.86 obv. 10 (NS)

Finally, next to maninkuwahh- 'to come near; to make short' and maninkuwantahh- 'to make short', there is maninkuwanu-, which is attested once in broken context (Bo $62387(\mathrm{NH})$ ), see Soysal, Yildiz Gülşen 2019: 4), so its meaning cannot be ascertained, but due to the productivity of the derivational model it must be something like 'to bring near' or 'to come near'.

There is no uniform chronological distribution of the suffixes in these pairs. Sometimes, the $a h h$-stem is the older and better attested one, as is the case of maninkuwahh-. By contrast, tepnu- is well attested since Middle Hittite (see Hoffner 1977: 152ff.), while tepawahh- is found only twice. Similarly, wastahh- is found twice in the same NS text (KUB 36.86), whereas wastanu- is attested five times, once in a NS copy of an Old Hittite text (KUB 13.3 I 6). The causatives kartimiyanu- and kartimiyahh- seem to be of the same age, both attested already in Middle Hittite, although kartimiyanu- is more frequent. Finally, taruppiyanu- and tarupp(iy)ahh- as well dankuwanu- and dankuwahh- are all attested one to three times in late texts.

4.3. The causative markers - $n u$ - and -ahh- were so productive that they started to replace or reinforce causatives formed with other markers. During the reign of Hattusili III, near the end of the Hittite kingdom, an infixed causative harnink- started to be replaced with a parallel $n u$ formation harganu-, also based on hark- 'to perish'. The nu-verb asesanu- derived from a reduplicated causative stem asās/ases- 'to settle, to install' is attested since the times of Mursili II. There seems to be a certain difference in their semantics: asesanu- usually means 'to settle', while asās/ases- may also mean 'to set up' or 'to install'. The editors of $\mathrm{HW}^{2}$ (A: 391f.) note that during the reign of Hattusili III the verb as ass/ases- virtually ceased to be used with the meaning 'to settle', which was relegated to asesanu-. Similarly, tittanu- is derived from a reduplicated causative stem titta/i- 'to install' and is attested mostly in late Hittite texts, although it appears once in a New Hittite copy of an Old Hittite text (KUB 25.1 VI 20, cf. Dempsey 2015: 143ff.).

4.4. The addition of the causative marker to an already causative stem in case of asesanu- and tittanu- as well as the replacement of the infixed stem harnink- with a nu-stem harganu- must have been motivated by the desire to make these stems more recognizable as causatives. By

${ }^{17}$ On tepawahh- cf. Hoffner 2009: 302, 390, note 267.

${ }^{18}$ Note that wastahh- does not have to be transitive and might be restored as [ŪL kuit]ki kuit wastahhun 'since I have not sinned anyhow'. According to Tischler (HEG W-Z: 408f., 412), wastanu- is a deverbal formation whereas wastahh-is denominal, but in my view both verbs may be denominal as well as deverbal. 
contrast, the parallel use of $n u$ - and ahh-causatives derived from the same adjective or verb is more difficult to justify. It is clear that the causative formations with - nu- and -ahh- were very productive. Nevertheless, this does not explain why tepawahh- 'to demean' appears in the Tawagalawa letter (CTH 181), while tepnu- with the same meaning had been in use since Middle Hittite. In my opinion, the formation of new causatives instead of using the available ones could be due to imperfect language competence by the scribes. As argued by Yakubovich (2010: 307f.), by the end of the New Hittite period the native language of the majority of scribes was Luwian. If so, the scribes had to learn Hittite, and it is conceivable that they were well acquainted with the productive patterns of causative derivation but could be not aware of their distribution with regard to certain verbs.

\section{Conclusions}

Five markers in total, all inherited from Proto-Indo-European, could be used to form causatives in Hittite. Even though Hittite preserved the reflexes of the most frequent PIE causative markers (suffix -e-< PIE *-éye/o-, infix -ni(n)-<PIE *-né/n-), they were no longer productive. Instead, morphologically more transparent suffixes $-n u$ - and -ahh- were employed in this role. The two suffixes under discussion owe their productivity partially due to the fact that they were deadjectival and could be added to virtually any descriptive adjective. Reduplication was mainly used to form imperfectives, so reduplicated causatives were rare. The coexistence of at least some parallel -nu- and -ahh-formations derived from the same root can be caused by the scribes' imperfect knowledge of Hittite.

\section{References:}

Aikhenvald, Alexandra. 2011. Causatives Which Do not Cause: Non-Valency-Increasing Effects of a ValencyIncreasing Derivation. In: A. Aikhenvald, R. Dixon (eds.). Language at Large: Essays on Syntax and Semantics: 86-142. Leiden - Boston: Brill.

CHD = Güterbock, Hans Gustav, Harry Hoffner, Theo van den Hout (eds.). 1980-. The Hittite dictionary of the Oriental Institute of the University of Chicago. University of Chicago.

Dempsey, Timothy Richard. 2015. Verbal Reduplication in Anatolian. PhD thesis. University of California, Los Angeles.

Eichner, Heinrich. 1969. Hethitisch u્šš-/uaššiia- "(Gewander) tragen; anziehen; bekleiden". Münchener Studien zur Sprachwissenschaft 27: 5-44.

Fortson, Benjamin Wynn. 2010. Indo-European Language and Culture: An Introduction. 2nd ed. Malden: Wiley-Blackwell. HEG = Tischler, Johann. 1977-. Hethitisches Etymologisches Glossar. Innsbruck.

Hoffner, Harry. 1977. Studies in Hittite Vocabulary, Syntax, and Style: Hommage a M. Emmanuel Laroche. Journal of Cuneiform Studies 29: 151-156.

Hoffner, Harry, 2009. Letters from the Hittite kingdom. Atlanta: Society of Biblical Literature.

Hoffner Harry, H. Craig Melchert. 2008. A Grammar of the Hittite Language. Winona Lake: Eisenbrauns.

$\mathrm{HW}^{2}=$ Friedrich, Johannes, Annelies Kammenhuber. 1975-. Hethitisches Wörterbuch: Zweite, völlig neubearbeite Auflage auf Grundlage der edierten hethitischen Texte. Heidelberg: Universitätsverlag Winter.

Kittilä, Seppo. 2009. Causative morphemes as non-valency increasing devices. Folia Linguistica 43: 67-94.

Kloekhorst, Alwin. 2008. Etymological Dictionary of the Hittite Inherited Lexicon. Leiden: Brill.

Koch, Harold. J. 1980. Indic dabhnóti and Hittite tepnu-: Etymological Evidence for an Indo-European Derived Verb Type. In: M. Mayrhofer, M. Peters, O. Pfeifer (eds.). Lautgeschichte und Etymologie. Akten der VI. Fachtagung der Indogermanischen Gesellschaft: 223-237. Wiesbaden: Reichert.

Kölligan, Daniel. 2004. Wenn zwei dasselbe tun: Iterativa und Kausativa. In: M. Kozianka, R. Lühr, S. Zeilfelder (eds.). Indogermanistik - Germanistik - Linguistik. Akten der Arbeitstagung der Indogermanischen Gesellschaft, Jena 18.-20.09.2002: 193-247. Hamburg: Dr. Kovač. 
Kölligan, Daniel. 2007. Iteratives and Causatives in Latin: a Unified Approach. In: C. George et al. (eds.). Greek and Latin from an Indo-European perspective: 49-64. Cambridge Philological Society.

Kronasser, Heinz. 1966. Etymologie der hethitischen Sprache. Wiesbaden: Harrassowitz.

Kulikov, Leonid. 2013. Constraints on the causative derivation in early Vedic: Evidence for a diachronic typology of transitivity. Poznań Studies in Contemporary Linguistics 49: 79-101.

Kümmel, Hans Martin. 1967. Ersatzrituale für den hethitischen König. StBoT 3. Wiesbaden: Harrassowitz.

Leumann, Manu. 1977. Lateinishen Laut- und Formenlehre. München: Beck.

LIV = Rix, Helmut (ed.). 2001. Lexikon der indogermanischen Verben. 2nd ed. Wiesbaden: Reichert.

Luraghi, Silvia. 2012. Basic Valency Orientation and the Middle Voice in Hittite. Studies in Language 36: 1-32.

Melchert, H. Craig. 1997. Denominative Verbs in Anatolian. In: Dorothy Disterheft, Martin E. Huld, John A. C. Greppin (eds.). Studies in Honor of Jaan Puhvel. Part One. Ancient Languages and Philology: 131-138. Washington D.C.: Institute for the Study of Man.

Melchert, H. Craig. 2018. Hittite tit(ta)nu-, titti-, and Lycian stta-. Chatreššar 1: 25-33.

Milizia, Paolo. 2004. Proto-Indo-European Nasal Infixation Rule. Journal of Indo-European Studies 32: 337-359.

Nedyalkov, Vladimir P., Georgij G. Silnitsky. 1973. The Typology of Morphological and Lexical Causatives. In: Ferenc Kiefer (ed.). Trends in Soviet Theoretical Linguistics: 1-32. Dordrecht: Springer.

Oettinger, Norbert. 1979. Die Stammbildung des hethitischen Verbums. Nürnberg: Verlag Hans Carl.

Sasseville, David. 2014-15. Luwian and Lydian agent nouns in *é-leh. Die Sprache 51/1: 105-24.

Sasseville, David. 2018. The Pre-History of the Verbal Stem Formation of the Luwic Languages. PhD thesis. Marburg University.

Schulze-Thulin, Britta. 2001. Zu hi-Konjugation von Fortsetzer urindogermanischer -o-éie/o-Kausativa/Iterativa im Hethitischen. In: O. Carruba, W. Meid (eds.). Anatolisch und Indogermanisch. Aktes des Kolloquiums der Indogermanischen Gesellschaft Pavia, 22.-25. September 1998: 381-393. Innsbruck: Institut für Sprachen und Literaturen der Universität Innsbruck.

Shatskov, Andrey. 2017. Hittite Nasal Presents. PhD thesis. Leiden University.

Shatskov, Andrey. Ms. (forthc.). The polysemy of the Hittite causative suffixes.

Soysal, Oğuz, Başak Yildiz Gülşen. 2019. Unpublished Bo-fragments in transliteration II. CHDS 3. Chicago: Oriental Institute of the University of Chicago.

Steer, Thomas. 2013-14. Die Entstehung der indogermanischen Nasal-Infix-Präsentien. Münchener Studien zur Sprachwissenschaft 67/2: 197-222.

Ünal, Ahmed. 1984. Studien über das hethitische Kriegswesen II: Verba Delendi harnink/harganu- 'vernichten, zugrunde richten'. Studi Micenei et Egeo-Anatolici 24: 71-85.

Watkins, Calvert. 1973. Hittite and Indo-European Studies: The Denominative Statives in $-\bar{e}$-. Transactions of the Philological Society 1971: 51-93.

Yakubovich, Ilya. 2010. Sociolinguistics of the Luvian Language. Leiden: Brill.

A. В. Шаццков. Хеттские показатели каузатива в диахронической перспективе анатолийских языков

В хеттском засвидетельствовано несколько морфологических маркеров каузатива. Два из них, суффиксы -nu- и -ahh-, были продуктивными, а остальные маркеры либо утратили свою продуктивность, либо, как в случае с редуплицированной основой, были в первую очередь маркерами итератива. В древнехеттский период -nu- и -ahh- всё еще находились в состоянии дополнительной дистрибуции, хотя в отдельных случаях уже могли присоединяться к одним и тем же типам основ (прилагательные на - $i$-). В среднеи новохеттский периоды эти суффиксы утратили какие-либо функциональные различия между собой и могли присоединяться к одним и тем же словам. Подобное сосуществование параллельных основ на -nu- и -ahh-может частично объясняться тем, что родным языком большинства писцов был лувийский, и их знание хеттского могло быть несовершенным.

Ключевые слова: хеттский язык; лувийский язык; каузативные образования; глагольная морфология; итеративные формы; интенсивные формы. 